\title{
Anticoagulant activity of heparin in intravenous fluids
}

\author{
TAKASHI OKUNO AND CHEERIE A. NELSON
}

From the Department of Haematology, Clinical Laboratories, Lutheran General Hospital, Park Ridge. Illinois 60068, USA

SYNOPSIS The anticoagulant activity of heparin dissolved in intravenous solutions was measuredo by two different methods of heparin assay. Both procedures showed markedly reduced anticoagulan@ activity within four hours after the addition of heparin to the solutions. When measured according to the procedure of Yin, heparin in the intravenous solutions fully regained its lost anticoagulant activity after 24 hours at room temperature. When measured by the thrombin time, however, the heparin anticoagulant activity remained reduced. The source of heparin, from either the lung of intestine, does not explain the reduction in anticoagulant activity. Although its cause is unknown the erratic behaviour of heparin in intravenous solutions stresses the importance of a laboratory monitor of heparin therapy.

While preparing the standard of heparin concentrations, one of us noted that, after a few hours at room temperature, heparin lost some of its anticoagulant activity. Because an increasing number of patients receive heparin in intravenous solutions for various coagulation disorders, we studied the stability of heparin added to various intravenous solutions using a recently introduced heparin assay method.

\section{Material and Methods}

Heparin assay was performed according to the procedure of Yin et al (1973). Trizmal buffer, cephalin in anticoagulant-free bovine plasma, and activated factor $\mathrm{X}$ stabilized in bovine serum were supplied by Sigma Co. (St. Louis, Mo). Heparin assay by thrombin time was done according to the procedure of Quick (1966). Thrombin was obtained from Parke-Davis (Detroit, Mich). Solutions of Ringer's lactate (Hartmann's), normal saline, 5\% dextrose, $10 \%$ dextrose, and $2 \frac{1}{2} \%$ dextrose in water were obtained from McGraw Laboratories (Milledgeville, Ga).

Sodium heparin (Upjohn Co., Kalamazoo, Mich and Medical Chemicals, Melrose Park, Ill) was dissolved in 250 to $500 \mathrm{ml}$ intravenous fluids at a final concentration of $10 \mathrm{u} / \mathrm{ml}$. Sodium heparin from Upjohn is prepared from beef lung and that

Received for publication 21 January 1975. from Medical Chemicals is from pig intestinas mucosa. Heparin concentrations were measured by both heparin assay procedures at 1 minute 2 hours, 4 hours, 6 hours, and 24 hours afte addition of sodium heparin. As a standard, hepario solution of $10000 \mathrm{u} / \mathrm{ml}$ was diluted with normat saline. To ensure that the heparin assay system were maintained constant throughout the experi ment, a small amount of heparin was draw aseptically from the same vial of the standard heparin solution at each determination. Standard ization of heparin was carried out three times te minimize any effects caused by dilution of the standard. To demonstrate further that dilution of the standard solution was kept within a reasonable range, the process was repeated ten times from the. same vial of heparin solution. All of the intravenouf solutions were stored at room temperature. Af the experiments were repeated six times on differen days.

\section{Results}

The results of heparin assay according to the pro ${ }^{+}$ cedures of Yin are shown in table I, and those by the thrombin time of Quick in table II. To demonstrate that the variation caused by dilution of standare heparin is minimal, the process of dilution was ree peated ten times from the same vial of standard hep arin. Minimal variation was observed (table V). Alf the data were a mean of six experiments on differen 


\begin{tabular}{|c|c|c|c|c|c|}
\hline & $\begin{array}{l}\text { Dextrose } \\
2.5 \%\end{array}$ & $\begin{array}{l}\text { Dextrose } \\
5 \%\end{array}$ & $\begin{array}{l}\text { Dextrose } \\
10 \%\end{array}$ & $\begin{array}{l}\text { Normal } \\
\text { Saline }\end{array}$ & $\begin{array}{l}\text { Ringer's } \\
\text { Lactate }\end{array}$ \\
\hline $\begin{array}{l}\text { Immediately after heparin } \\
2 \text { hours } \\
4 \text { hours } \\
6 \text { hours } \\
24 \text { hours }\end{array}$ & $\begin{array}{r}10.01 \pm 0.11 \\
7.46 \pm 2 \cdot 00 \\
6.66 \pm 2 \cdot 70 \\
5 \cdot 20 \pm 2 \cdot 44 \\
9.46 \pm 0.65\end{array}$ & $\begin{array}{r}10 \cdot 02 \pm 0 \cdot 10 \\
7 \cdot 38 \pm 2 \cdot 27 \\
4 \cdot 54 \pm 1 \cdot 11 \\
4 \cdot 88 \pm 2 \cdot 98 \\
10 \cdot 15 \pm 1 \cdot 12\end{array}$ & $\begin{array}{l}9 \cdot 97 \pm 0 \cdot 12 \\
9 \cdot 67 \pm 2 \cdot 98 \\
7 \cdot 50 \pm 3 \cdot 07 \\
6 \cdot 10 \pm 4 \cdot 78 \\
8 \cdot 42 \pm 1 \cdot 94\end{array}$ & $\begin{array}{r}10 \cdot 03 \pm 0 \cdot 13 \\
6 \cdot 62 \pm 2 \cdot 98 \\
5 \cdot 84 \pm 2 \cdot 14 \\
4 \cdot 55 \pm 2 \cdot 25 \\
8 \cdot 75 \pm 2 \cdot 63\end{array}$ & $\begin{array}{r}10 \cdot 02 \pm 0 \cdot 10 \\
6 \cdot 34 \pm 2 \cdot 44 \\
5 \cdot 34 \pm 2 \cdot 43 \\
4 \cdot 08 \pm 3 \cdot 46 \\
7 \cdot 90 \pm 2 \cdot 59\end{array}$ \\
\hline
\end{tabular}

Table I Anticoagulant activity of heparin $(\mathrm{u} / \mathrm{ml})$ according to the procedure of Yin

\begin{tabular}{|c|c|c|c|c|c|}
\hline & $\begin{array}{l}\text { Dextrose } \\
2.5 \%\end{array}$ & $\begin{array}{l}\text { Dextrose } \\
5 \%\end{array}$ & $\begin{array}{l}\text { Dextrose } \\
10 \%\end{array}$ & $\begin{array}{l}\text { Normal } \\
\text { Saline }\end{array}$ & $\begin{array}{l}\text { Ringer's } \\
\text { Lactate }\end{array}$ \\
\hline $\begin{array}{l}\text { Before heparin } \\
\text { Immediately after } \\
2 \text { hours } \\
6 \text { hours } \\
24 \text { hours }\end{array}$ & $\begin{array}{r}9.57 \pm 0.06 \\
22 \cdot 10 \pm 1 \cdot 21 \\
18 \cdot 45 \pm 0.34 \\
11.08 \pm 0.12 \\
10.58 \pm 0.06\end{array}$ & $\begin{array}{r}9.55 \pm 0.06 \\
22 \cdot 10 \pm 0.54 \\
22 \cdot 20 \pm 1 \cdot 47 \\
15.58 \pm 0 \cdot 18 \\
16.40 \pm 0.13\end{array}$ & $\begin{array}{r}9 \cdot 58 \pm 0.06 \\
23 \cdot 30 \pm 0.46 \\
20 \cdot 50 \pm 2 \cdot 16 \\
15 \cdot 28 \pm 0.06 \\
18.05 \pm 0.27\end{array}$ & $\begin{array}{r}9 \cdot 58 \pm 0.06 \\
22 \cdot 00 \pm 1 \cdot 44 \\
18 \cdot 10 \pm 0 \cdot 44 \\
16 \cdot 10 \pm 0 \cdot 14 \\
17 \cdot 18 \pm 0 \cdot 13\end{array}$ & $\begin{array}{r}9.50 \pm 0.06 \\
22.08 \pm 1.43 \\
17.05 \pm 0.12 \\
10.54 \pm 0.18 \\
10.55 \pm 0.06\end{array}$ \\
\hline
\end{tabular}

Table II Anticoagulant activity of heparin (seconds) by the thrombin time of Quick

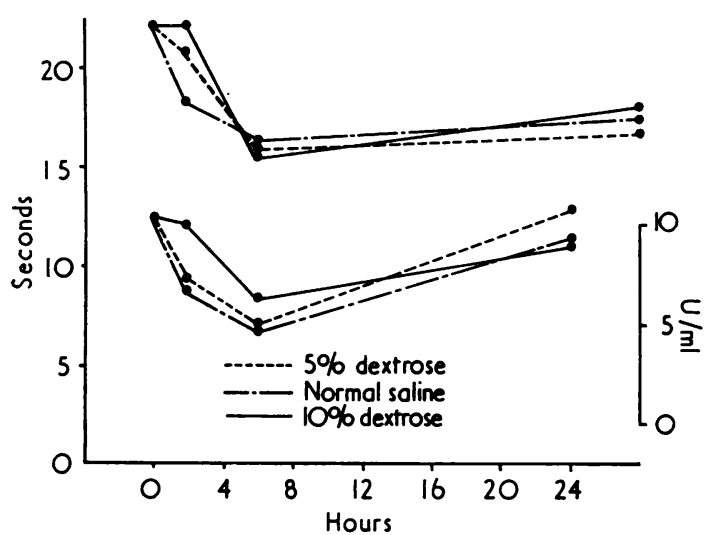

Figure Anticoagulant activity of heparin in intravenous solutions measured by the thrombin time (upper trace) and by the procedure of Yin (lower trace).

days and their standard deviations. Heparin quickly lost its anticoagulant activity within two hours in dextrose, normal saline, and Ringer's lactate solutions. The loss of heparin activity was demonstrated

\begin{tabular}{|c|c|c|}
\hline & $\begin{array}{l}\text { Heparin } \\
(u / m l)\end{array}$ & $\begin{array}{l}\text { Thrombin Time } \\
\text { (sec) }\end{array}$ \\
\hline $\begin{array}{l}\text { Without heparin } \\
1 \text { min } \\
2 \text { hours } \\
4 \text { hours } \\
6 \text { hours } \\
24 \text { hours }\end{array}$ & 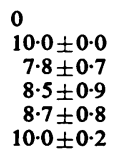 & $\begin{array}{r}5.9 \pm 0.8 \\
26 \cdot 5 \pm 0.6 \\
26 \cdot 8 \pm 1 \cdot 0 \\
26 \cdot 0 \pm 1 \cdot 2 \\
26 \cdot 8 \pm 0.7 \\
26 \cdot 8 \pm 1 \cdot 4\end{array}$ \\
\hline
\end{tabular}

Table III Heparin assay and thrombin time in $500 \mathrm{ml}$ distilled water in assays by both procedures. The activity of heparin reached its nadir at six hours. The $\mathrm{pH}$ of the solutions remained stable throughout the experiment, ranging from 5.5 to 6.9. The results of assay of anticoagulant activity of heparin in $500 \mathrm{ml}$ distilled water are shown in table III. A loss of anticoagulant activity is observed with the procedure of Yin, while the thrombin time remains unchanged. Table IV shows the anticoagulant activities of heparin from two different sources measured by the thrombin time in normal saline solution. No difference between the two preparations is demonstrated. Similar results are obtained in $2 \frac{1}{2} \%, 5 \%$, and $10 \%$ dextrose and Ringer's lactate solution.

\begin{tabular}{llr}
\hline & \multicolumn{1}{l}{$A$} & \multicolumn{1}{l}{$B$} \\
\hline Before heparin & $10 \cdot 03 \pm 0.00$ & $9 \cdot 90 \pm 0 \cdot 10$ \\
Immediately after & $21 \cdot 67 \pm 1 \cdot 70$ & $22 \cdot 33 \pm 1 \cdot 70$ \\
2 hours & $18 \cdot 67 \pm 0.48$ & $17 \cdot 67 \pm 0.62$ \\
6 hours & $16 \cdot 27 \pm 0.20$ & $16.07 \pm 0 \cdot 24$ \\
24 hours & $17 \cdot 40 \pm 0.28$ & $17 \cdot 20 \pm 0.00$ \\
\hline
\end{tabular}

Table IV Anticoagulant activity of heparin from lung preparation $(A)$ and intestine preparation $(B)$ measured by the thrombin time of Quick (seconds)

\begin{tabular}{lll}
\hline & Seconds & Units $/ \mathrm{ml}$ \\
\hline Mean & $57 \cdot 06$ & $9 \cdot 71$ \\
Range & $54 \cdot 0-58 \cdot 8$ & $9 \cdot 2-10 \cdot 0$ \\
Standard deviation & $2 \cdot 08$ & $0 \cdot 36$ \\
Coefficient variation & 3.65 & $3 \cdot 70$ \\
$(\%)$ & & \\
\hline
\end{tabular}

Table V Variation of heparin standard according to the process of dilution $(n=10)$ 


\section{Discussion}

Heparin is often added to intravenous fluids and thus is continuously infused for as long as $\mathbf{2 4}$ hours. This method of administration is generally regarded as obtaining a stable anticoagulant activity throughout, once the infusion rate has been adjusted (Genton, 1974). It is known that the dose of heparin needed is related to body weight and is influenced by the condition of the patient, such as shock, fever, hepatic function, and the presence of active thrombosis. However, little is known about the effect of intravenous fluids on the anticoagulant activity of heparin. The literature is not only scarce but is conflicting (Stock and Warner, 1971; Jacobs et al, 1973).

The conflicting reports on the stability of heparin in intravenous fluids appear, in part, to result from the rather insensitive and inaccurate heparin assay methods that the studies were based upon; all these studies used the thrombin time or its modification. This method lacks sensitivity and specificity, especially at low heparin levels (Yin et al, 1973). The anticoagulant activity of heparin is complex. It is generally thought that heparin enhances an alpha-2 globulin molecule in plasma, which is also known as the plasma inhibitor. The plasma inhibitor interferes with thrombin and therefore blocks the conversion of fibrinogen to fibrin (Genton, 1974). Recently the inhibitor has been reported to serve as an inhibitor of activated factor $\mathbf{X}$ and thereby to interfere with the conversion of prothrombin to thrombin (Yin et al, 1973). Based on the latter mechanism, a new heparin assay method was introduced by Yin et al. This measures submicrograms of heparin with a high reproducibility.

Using this procedure, our study showed an initial loss of heparin activity in intravenous fluids; activity was fully recovered after 24 hours. This pattern of loss of anticoagulant activity was seen in all the fluids tested $-2 \frac{1}{2} \%$ dextrose, $5 \%$ dextrose, $10 \%$ dextrose, normal saline, and Ringer's lactate solutions. This is in sharp contrast to the study of Jacobs et al who, using a modified thrombin time, found that heparin in normal saline did not lose its anticoagulant activity for 24 hours. Although they observed a substantial loss of heparin activity in other intravenous fluids $(4.3 \%$ dextrose with $0 \cdot 18 \%$ sodium chloride, lactate, and $5 \%$ dextrose), they failed to detect the rebound of anticoagulant activity after 24 hours. Our studies, using the thrombin time, also failed to show a full recovery of heparin anticoagulant activity in 24 hours. The heparin assay used in their study is rather insensitive. The moderate insensitivity of heparin assay based on the thrombin time is also demonstrated in table III. In this table an experiment was done using $500 \mathrm{ml}$ distilled water added to heparin. While the procedure of Yin detected a moderate loss of anticoagulanto activity, the thrombin time remained unchanged throughout the experiment. Chessells et al (1972) $\frac{\bar{w}}{\vec{b}}$ using a within-patient cross-over trial to compare $\stackrel{\mathbb{\Phi}}{\Omega}$ $5 \%$ dextrose and $5 \%$ sorbitol as diluents for heparin, demonstrated no detectable loss of heparin activity in either solution. The in vivo study of Chessells. et al may not prove or disprove the results of the $\vec{\omega}$ in vitro studies, because of accumulative anticoagu- $\stackrel{\Omega}{\Omega}$ lant activity in the body, which may obviate the in vitro determination, and because of its in vivoin metabolism which is relatively unknown (Genton, $\infty$ 1974). Furthermore, the partial thromboplastin time used in their study may not accurately reflect the $\AA$ anticoagulant activity produced by heparin. The을 inaccuracy of partial thromboplastin time forheparin control has been reported recently (Congdon $ᄃ$ et al, 1973); (Pitney et al, 1970). A low pH was also stated to influence the anticoagulant activity of $\vec{\omega}$ heparin (Stock and Warner, 1971). Our study, however, showed a fairly stable pH of the intravenous fluids throughout the experiments and none of theo fluids was below pH 3, a critical level below which the anticoagulant activity of heparin is reportedlyo inhibited.

The reason for a temporary loss of heparin activity is not known and further study is needed. Several $\overrightarrow{0}$ reasons are conceivable: heparin transiently alters 3 its molecule in fluids; heparin is insufficiently? dissolved in solutions; the fluids interfere with the plasma inhibitor or they influence the conversiono of various coagulation stages. Whatever the cause, such capricious behaviour of heparin in fluids stresses the importance of a regular heparin monitor in: patients undergoing heparin therapy, in contrast toß the opinion of those who prefer a selected schedule of heparin administration which requires no laboratory control (Bauer, 1964).

\section{References}

Bauer, G. (1964). Clinical experiences of a surgeon in the use of heparin. Amer. J. Cardiol., 14, 29-35.

Chessells, J. M., Braithwate, T. A., and Chamberlain, D. A.ర (1972). Dextrose and sorbitol as diluents for continuous intravenous heparin infusion. Brit. med. J., 2, 81-82.

Congdon, J. E., Kardinal, C. G., and Wallin, J. D. (1973). Monitoring heparin therapy in hemodialysis. J. Amer? med. Ass., 226, 1529-1533.

Genton, E. (1974). Guidelines for heparin therapy. Ann intern. Med., 80, 77-82.

Jacobs, J., Kletter, D., Superstine, E., Hill, K. R., Lynn, B. and Webb, R.A. (1973). Intravenous infusions of heparin and penicillins. J. clin. Path., 26, 742-746.

Pitney, W. R., Pettit, J. E., and Armstrong, L. (1970) Control of heparin therapy. Brit. med. J., 4, 139-141. 
Quick, A. J. (1966). Hemorrhagic Diseases and Thrombosis, 2nd edition, p. 418. Lea and Febiger, Philadelphia.

Stock, S. L. and Warner, N. (1971). Heparin in acid solutions. (Letter). Brit. med. J., 3, 307.
Yin, E. T., Wessler, S., and Butler, J. V. (1973). Plasma heparin: a unique, practical, submicrogram-sensitive assay. J. Lab. clin. Med., 81, 298-310.

\section{The May 1975 Issue}

\section{THE MAY 1975 ISSUE CONTAINS THE FOLLOWING PAPERS}

Anaemic crisis in sickle cell disease J. R. MANN, K. P. COTTER, R. A. WALKER, G. W. G. BIRD, AND J. STUART

Storage of blood and the mean corpuscular volume A. C. K. LAWRENCE, J. M. BEVINGTON, AND M. YOUNG

Two cases of sodium azide poisoning by accidental ingestion of Isoton S. G. N. RICHARDSON, C. GILES, AND C. H. J. SWAN

Thrombolytic therapy and myocardial infarction C. L. BERRY

Pulmonary oedema at necropsy: a combined pathological and radiological method of study GERARD SLAVIN, LOUIS KREEL, AMANDA HERBERT, AND BRENDA SANDIN

Intestinal polyps in the Nigerian African A. OLUFEMI WILLIAMS AND D. L. PRINCE

Reduced lymphocyte transformation in early cancer of the breast LOUISE A. KNIGHT AND WILLIAM M. DAVIDSON

The detection of specific IgM antibodies following infection with rubella virus J. R. PATTISON AND JENNIFER E. MACE

Serological diagnosis of congenital toxoplasmosis K. A. KARIM AND G. B. LUDLAM

Antibiotic-disc tests for rapid identification of non-sporing anaerobes SUSAN PEACH
Effects of delayed culture on semiquantitative urinary bacteriology results T. L. SHRESTHA

A clinico-pathological study of vulval dermatoses P. C. LEIGHTON AND F. A. LANGLEY

Effects of minocycline and tetracycline on the vaginal yeast flora J. D. ORIEL AND PAMELA M. WATERWORTH

An experimental comparison of Thiol broth with Brewer's thioglycollate for anaerobic blood cultures D. C. SHANSON AND M. BARNICOAT

Comparison of the sensitivity of human embryo kidney cells, HeLa cells, and WI38 cells for the primary isolation of viruses from the eye D. A. MCSWIGGAN, S. DAROUGAR, A. F. M. S. RAHMAN, AND JULIA A. GIBSON

Serum enzyme levels in alcoholism and drug dependency SHANTA PATEL AND P. O'GORMAN

The concentration of cerebrospinal fluid potassium during systemic disturbances of acid-base metabolism M. A. SAMBROOK

\section{Technical Method}

Application of the Stomacher for rapid homogenization of sputum and the serial streak dilution method for quantitative culture V. J. MITCHELL AND A. R. HARVEY

Letters to the Editor

Book reviews

Copies are still available and may be obtained from the PUBLISHING MANAGER, BRITISH MEDICAL ASSOCIATION, TAVISTOCK SQUARE, LONDON, WC1H 9JR, price $£ 2.00$ 